\title{
Hubungan Implementasi Praktik Berbasis Industri Kewirausahaan, Minat Belajar dan Kreativitas dengan Kesiapan Berwira Usaha Siswa
}

\section{The Relationship between the Implementation of Entrepreneurship Industry-Based Practices, Learning Interest and Creativity with Students' Business Readiness}

\author{
Masliha*, Achmad Hufad, \& Maman Fathurrohman \\ Universitas Sultan Ageng Tirtayasa, Tangerang, Jakarta, Indonesia \\ 7782200021@untirta.ac.id*
}

Naskah diterima tanggal 4/01/2021, direvisi akhir tanggal 3/04/2021, disetujui tanggal 30/04/2021

\begin{abstract}
Abstrak
Penelitian ini bertujuan untuk mengetahui hubungan implementasi praktik berbasis industri kewirausahaan, minat belajar dan kreativitas dengan kesiapan berwira usaha siswa SMK Negeri 1 Kabupaten Tangerang. Metode yang gunakan yakni motode penelitian kuantitatif dan survei, yang akan di berikan kepada siswa kelas XI multimedia SMK Negeri 1 Kabupaten Tangerang. Variabel dependen pada penelitian ini adalah implementasi praktik berbasis industri kewirausahaan $\left(\mathrm{X}_{1}\right)$, minat belajar $\left(\mathrm{X}_{2}\right)$, dan kreativitas $\left(\mathrm{X}_{3}\right)$. Sedangkan variabel independen adalah kesiapan berwira usaha (Y). Dari hasil pengujian hipotesis satu sampai dengan empat menunjukan adanya hubungan positif dan signifikan antar variabel. Penelitian ini juga menunjukkan pengaruh implementasi praktik berbasis industri kewirausahaan sebesar 18,1\% terhadap kesiapan berwira usaha. Pengaruh minat belajar sebesar $65 \%$ terhadap kesiapan berwira usaha. Pengaruh kreativitas sebesar 26,3\% terhadap kesiapan berwira usaha. Pengaruh ketiga variabel tersebut sebesar $42,9 \%$ kesiapan berwirausaha.
\end{abstract}

Kata kunci: Berwirausaha; Kreativitas; Minat Belajar; Implementasi Praktik berbasis Kewirausahaan.

\begin{abstract}
This study aims to determine the relationship between entrepreneurship industry-based implementation, interest in learning, and creativity with SMK Negeri 1 Tangerang Regency students' entrepreneurial readiness. This research uses a quantitative approach and survey methods. The sample in this study were class XI students of the Multimedia Expertise Program at SMK Negeri 1 Tangerang Regency. The independent variables in this study are the implementation of industry-based entrepreneurship practices (X1), interest in learning (X2), and creativity (X3). At the same time, the dependent variable is entrepreneurial readiness $(Y)$ testing requirements analysis in research using the normality test and homogeneity test. The results of testing the data analysis requirements show that the data is normally distributed and homogeneous. The results of hypothesis testing one to four show a positive and significant relationship between variables. This study also shows the implementation of industry-based entrepreneurship practice at $18.1 \%$ towards entrepreneurship readiness. The effect of interest in learning is $65 \%$ on entrepreneurship readiness. The impact of creativity is $26.3 \%$ on entrepreneurial enthusiasm. The impact of these three variables is $42.9 \%$ on entrepreneurship readiness.
\end{abstract}

Keywords: Creativity; Entrepreneurship; Interest in Learning; Implementation of Industry-based Practice of Entrepreneurship. 


\section{PENDAHULUAN}

Pengangguran di indonesia saat ini cukup tinggi. pada bulan Februari 2012 BPS mencatat total jumlah pengangguran di indonesia mencapai 7,2 juta orang atau $6,14 \%$ dari total angkatan kerja (BPS, 2012). Salah satu penyebab meningkatnya jumlah pengganguran di indoenesia di sebabkan oleh sumber daya manusia (SDM) di indoensia masih kurang kompeten atau tenaga kerja yang dihasilkan oleh sekolah dan perguruan tinggi jauh lebih banyak di bandingkan dengan peluang kerja yang tersedia.

Kompetensi SDM yang masih terbilang rendah menjadi salah satu penyebab jumlah pengangguran terus meningkat, dan peluang kerja yang tidak bisa menampung jumlah tenaga kerja baik dari perguruan tinggi dan juga sekolah memjadi tugas untuk pemerintah. Dalam hal ini pemerintah memberikan kebijakan untuk meningkatkan kualitas SDM melalui pendidikan.

Dengan menanamkan jiwa wirausaha disetiap jenjang pendidikan akan membuka peluang untuk tenaga kerja baru. Salah satu strategi yang dibuat ialah dengan mengembangkan program pembelajaran melalui berbagai program seperti kelas kewirausahaan, kelas industri, dan teaching factory atau teaching industry, di SMK (Hamdani, 2011). Kebijakan ini diaharapkan dapat memberikan keseimbangan antara lapangan kerja, pencari kerja dan pencari kerja yang berkualitas.

Pembelajaran dengan implementasi praktik berbasis industri kewirausahaan di SMK diharapkan akan menjadi salah satu alat daya tarik tersendiri sehinggga mampu membangkitkan kreativitas dan minat belajar pada mata pelajaran kewirausahaan yang sangat baik dalam pembelajaran. SMK sebagai lembaga pendidikan yang menyiapkan tenaga kerja tidak hanya memfokuskan pada penyiapan tenaga kerja untuk mengisi lapangan pekerjaan di industri, tapi juga siap mengisi lapangan pekerjaan pada sektor informal bahkan harus siap bila harus membuka usaha sendiri atau lapangan kerja bagi dirinya dan orang lain.

Implementasi praktik berbasis industri kewirausahaan yang di selenggarakan di SMK Negeri 1 Kabupaten Tangerang ini mengacu pada konsep implementasi teaching industry/factory, Competensi Based Training (CBT), Work Based Learning (WBL), Production Based Training (PBT).

Pembelajran sekolah menengah kerujuran dituntut untuk mencetak lulusan tenaga kerja yang kompeten dibidangnya ataupun menjadi seorang interprenuer. Dengan praktik berbasis industri kewirausahaan siswa dapat mengenal secara langsung dunia indusri, mengikuti kualitas industri yang terkait dengan waktu untuk mencapai target industri, mengasah kompetensi keahliannya, membangun mental dengan observasi langsung dengan lingkungan kerja. Dengan begitu siswa dapat membangun wirausaha dengan standar mutu industri yang siap bersaing dan membuka lapangan kerja untuk tenaga kerja lain.

Proses implementasi praktik berbasis industri kewirausahaan ini memadukan konsep bisnis dan pendidikan kejuruan sesuai dengan kompetensi keahlian yang relevan, misalnya: pada kompetensi keahlian Mutimedia melalui kegiatan pembuatan dan penjualan souvenir dengan proses digital printing dikerjakan oleh peserta didik.

Secara umum implementasi praktik berbasis industri kewirausahaan ini ini bertujuan untuk melatih siswa mencapai ketepatan waktu, kualitas yang dituntut oleh industri, mempersiapkan siswa sesuai dengan kompetensi keahliannya, menanamkan mental kerja dengan beradaptasi secara langsung dengan kondisi dan situasi inndustri, menguasai kemampuan manajerial dan mampu menghasilkan produk jadi yang mempunyai standar mutu industri.

Implementasi praktik berbasis industri kewirausahaan ini, maka penulis memberikan kesimpulan bahwa implementasi praktik berbasis industri kewirausahaan adalah suatu proses pembelajaran keahlian dan keterampilan yang dirancang dan dilaksanakan berdasarkan prosedur dan standar bekerja yang sesungguhnya untuk mengahsilkan barang dan jasa yang diselenggarakan di sekolah dengan mengembangkan sikap dan jiwa wira usaha siswa.

Djamarah (2011) minat adalah kebiasan memperhatikan mengingat beberapa aktivitas. Minat yang terjadi pada seseorang akan 
membuat orang tersebut terus memperhatian aktivitas secara kositen dengan rasa senang. Sudaryono (2012) merumuskan konsep minat sebagai kesadaran yang muncul pada individu yang memperhatiakan suatu objek dengan rasa senang.

Minat besar pengaruhnya terhadap aktivitas belajar. Anak didik yang berminat terhadap suatu mata pelajaran akan mempelajarinya dengan sungguh-sungguh, karena ada daya tarik baginya. Anak didik mudah menghapal pelajaran yang menarik minatnya. Proses belajar akan berjalan lancar bila disertai minat. Minat merupakan alat motivasi yang utama yang dapat membangkitkan kegairahan belajar siswa dalam rentang waktu tertentu.

Berdasarkan beberapa pengertian minat menurut para ahli tersebut, penulis menyimpulkan foktor foktor yang terkandung dalam minat sebagai berikut: (1) Minat terjadi karena gejala psikologis; (2) Rasa ketertarikan dengan suatu objek atau aktivitas; (3) Memiliki perasaan senang saat memperhatikan objek atau aktivitas tersebut. (4) Ada dorongan dari diri subjek untuk melakukan seperti yang sudah diperhatikan; dan (5) Minat adalah gejala psikologis yang menunjukan bahwa adanya kemauan atau kecendrungan untuk memperhatikan suatu objek atau aktivitas dengan perasaan senang kepada objek atau aktiviitas tersebut.

Kreativitas merupakan aktivitas dinamis seseorang dengan melibatkan dengan melibatkan alam bawah sadar maupaun alam sadar seseorang. Kreativitas adalah kemampuan individu dalam mendapatkan pengembangan ide atau gagasan dari pengalaman untuk memecahkan suatu masalah. Kreativitas melibatkan keseluruhan otak. Mempergunakan kedua belahan otak, otak kiri dan otak kanan untuk menciptakan sesuatau ataupun memberikan inovasi.

Manusia dituntut memikirkan dan bertindak dengan berbagai cara untuk dapat menguraikan kompleksitas tantangan dan memikirkan berbagai alternatif tndakan yang dapat dilakukan untuk menghadapi tantatangan, utuk itulah manusia membutuhkan kreativitas. Kemampuan beradaptasi dipengaruhi oleh bagaimana manusia memandang suatu permasalahan.
Apakah permasalahan dianggap sesuatu yang menyulitkan, merugikan dan mengancam diri atau permasalahan dipandang sebagai tantangan yang membuat diri menjadi lebih tahu, terampil atau mampu bertindak lebih baik.

Berdasarkan uraian di atas maka penulis dapat menyimpulkan bahwa kreativitas adalah kemampuan individu untuk mempergunakan imaginasi dan berbagai kemungkinan yang diperoleh dari interaksi dengan ide atau gagasan, orang lain dan lingkungan untuk membuat koneksi dan hasil yang baru serta bermakna.

Pandangan kreatif wiraushaan dalam memanfaatkan peluang yang bahkan tidak dilihat oleh orang banyak dan dikonfersikan menjadi sebuah usaha yang inovatif Timmons (1978) dari pengertian tersebut penulis menyimpulkan bahwa kewirausahaan yaitu kemampuan dalam mengembangkan persusahaan atau membuat usaha dengan melihat sebuah peluang dengan menggabungkan prinsip, semangat, kiat, semangat, nilai-nilai, dan tindakan yang nyata.

Karakteristik tersebut menunjuk kepada sejumlah kompetensi yang harus dimiliki oleh seorang wirausahawan secara menyeluruh. Kompetensi tersebut sudah siswa pelajari dalam pembelajaran di sekolah dengan harapan siswa dapat menjadi seorang wirausahawan yang mempunyai prinsip, semangat, kiat, semangat, nilai-nilai, dan tindakan yang nyata. seorang wira usaha dalam hal ini harus memiliki jiwa dan kemampuan yang bersifat kreatif dan inovatif, mampu menciptakan sesuatu yang baru, mampu memulai usaha, mampu mencari pelauang, berani menanggung resiko serta mampu mengembangkan ide dan meramu sumber daya.

Dari uraian di atas penulis menyimpulkan bahwa kesiapan berwirausaha adalah kondisi yang terdapat dalam diri seseorang yang memenuhi persayaratan baik secara mental, fisik, dan kesiapan dari segi kognitif dan sebagainya untuk dapat mengembangkan potensi dirinya sehingga mempunyai kemampuan untuk melakukan kegiatan wirausaha. 


\section{METODE PENELITIAN}

Untuk mengetahui hubungan antara implementasi praktik berbasis industri kewirausahaan, minat belajar dan kreativitas dengan kesiapan berwirausaha siswa SMK Negeri 1 Kabupaten Tangerang adalah dengan menggunakan penelitian deskriptif analisis menggunakan metode survey teknik korelasional dengan pendekatan kuantitatif. Penelitian kuantitatif Menurut Sugiyono (2010), Adapun variabel bebas atau dependen dalam penelitian ini adalah implementasi praktik berbasis industri kewirausahaan (X1), minat belajar (X2), dan kreativitas (X3). Sementara itu, variabel terikat atau independen adalah kesiapan berwirausaha (Y).

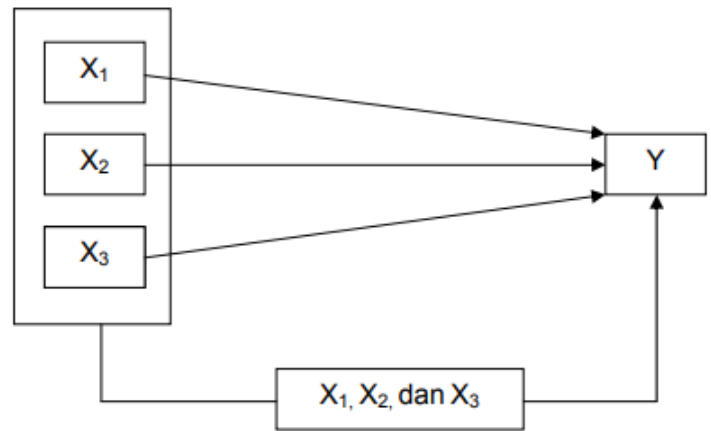

Gambar 1. Variabel penelitian

Probablity Sampling menjadi pilihan teknik pengambilan data pada penelitian ini. Teknik pengambilan sampel dengan probablity sampling membuat setiap elemen populasi mempunyai kesempatan yang sama (Sugiyono, 2010).

\subsection{Uji Validitas}

Uji validitas merupakan salah satu langkah penting untuk mengukur kesamaan antara data yang terkumpul dengan data yang sesungguhnya terjadi pada obyek yang diteliti. Menurut pendapat Sugiyono (2010), interument dapat dikatakan valid jika dapat mengukur yang seharusnya diukur. Dengan demikian, instrumen yang valid akan menghasilkan hasil penelitian yang valid pula. 2.2. Uji Normalitas Data

Uji ini dimaksudkan untuk menentukan normal tidaknya distribusi data penelitian. Uji normalitas data yang digunakan pada penelitian ini adalah chi kuadrat. Data dinyatakan normal bila harga $\chi^{2}$ hitung $<\chi^{2}$ tabel yang diuji pada taraf signifikansi 0.05.
2.3. Uji Homogenitas Data

Uji Homogenitas untuk bisa menguji kesamaan varians antara dua kelompok yang dibandingkan. peneliti melakukannya dengan teknik Analisis Varian Homogenitas Uji F. Adapun kriteria pengujian yang dipergunakan adalah pada taraf signifikansi 5\% yang memiliki arti bahwa data bisa dikatakan homogeny jika $F_{\text {hitung }}<\mathrm{F}_{\text {tabel. }}$.

2.4. Uji Hipotestis

Dalam menguji hipotesis pertama tentang hubungan antara implementasi praktik berbasis kewirausahaan dengan kesiapan berwira usaha, hipotesis kedua tentang hubungan antara minat belajar dengan kesiapan berwirausaha siswa dan hipotesis ketiga tentang hubungan antara kreativitas dengan kesiapan berwirausaha siswa, pada penelitian ini, penulis menggunakan rumus sebagai berikut:

$$
r_{X Y}=\frac{N \Sigma X Y-(\Sigma X)(\Sigma Y)}{\sqrt{\left\{N \Sigma X^{2}-(\Sigma X)^{2}\right\}\left\{N \Sigma Y^{2}-(\Sigma Y)^{2}\right\}}}
$$

Keterangan :

$\mathrm{N}=$ Jumlah subyek rxy $=$ Koefisien korelasi antara variabel $\mathrm{x}$ dan variabel $\mathrm{y}$ $\sum \mathrm{X}=$ Jumlah skor butir $\mathrm{x}$ $\sum \mathrm{Y}=$ Jumlah skor butir $\mathrm{y}$ $\sum X Y=$ Jumlah hasil kali butir $\mathrm{x}$ dan $\mathrm{y}$ $\sum X 2=$ Jumlah kuadrat butir $\mathrm{X}$ $\sum \mathrm{Y} 2=$ Jumlah kuadrat butir $\mathrm{y}$ $\left(\sum X\right) 2=$ Hasil kuadrat dari jumlah skor butir $\mathrm{x}$ $\left(\sum Y\right) 2=$ Hasil kuadrat dari jumlah skor butir $\mathrm{y}$

\section{HASIL DAN PEMBAHASAN}

Melihat prediksi seberapa tinggi nilai variabel independen dalam penelitian ini digunakan persamaan regresi, dalam hal ini kesiapan berwira usaha siswa, bila nilai variabel independen, dalam hal ini Implementasi praktik Berbasis Industri Kewirausahaan, dimanipulasi atau diubahubah. Rumus dari persamaan regresi sebagai berikut: $\mathrm{Y}^{\prime}=\mathrm{a}+\mathrm{bX}$

Berdasarkan perhitungan, ditemukan harga $a=40,62$ dan harga $b=0,52$. Maka persamaan regresi untuk hubungan Implementasi praktik Berbasis Industri Kewirausahaan dengan kesiapan berwira 
usaha siswa adalah sebagai berikut: $\mathrm{Y}^{\prime}=40,62$ $+0,52 \mathrm{X}$ Dari hasil perhitungan di atas, dapat disimpulkan antara Implementasi praktik Berbasis Industri Kewirausahaan dengan kesiapan berwira usaha siswa mempunyai hubungan yang positif.

Persamaan regresi untuk minat belajar dengan kesiapan berwira usaha siswa adalah sebagai berikut: $Y^{\prime}=15,99+0,86 \mathrm{X}$ Dari hasil perhitungan di atas, dapat disimpulkan antara minat belajar dengan kesiapan berwira usaha siswa mempunyai hubungan yang positif.

Persamaan regresi untuk hubungan kreativitas dengan kesiapan berwira usaha siswa adalah sebagai berikut: $\mathrm{Y}^{\prime}=50,13+$ 0,44X Dari hasil perhitungan di atas, dapat disimpulkan antara kretivitas dengan kesiapan berwira usaha siswa mempunyai hubungan yang positif.

Persamaan regresi untuk hubungan implementasi praktik berbasis industri kewirausahaan, minat belajar, dan kreativitas dengan kesiapan berwira usaha siswa adalah sebagai berikut: $\mathrm{Y}^{\prime}=9,352+0,135 \mathrm{X} 1+$ 0,891X2 + -0,096X3 Berdasarkan uraian di atas, dapat ditarik kesimpulan bahwa terdapat hubungan positif antara implementasi praktik berbasis industri kewirausahaan, minat belajar, dan kreativitas dengan kesiapan berwira usaha siswa.

Secara keseluruhan, penelitian ini menunjukan bahwa terdapat hubungan positif antara implementasi praktik berbasis industri kewirausahaan dengan kesiapan berwira usaha, minat belajar dengan kesiapan berwira usaha, kreativitas dengan kesiapan berwira usaha, dan implementasi praktik berbasis industri kewirausahaan, minat belajar, dan kreativitas dengan kesiapan berwira usaha.

\section{KESIMPULAN}

Berdasarkan hasil pengujian dan pembahasan dapat disimpulkan pertama terdapat hubungan positif dan signifikan antara implementasi praktik berbasis industri kewirausahaan dengan kesiapan berwira usaha, dengan perolehan koefisien determinasi sebesar $(0,426) 2=0,18$ dan persamaan regresi $\mathrm{Y}^{\prime}=40,62+0,52 \mathrm{X}$. Hal ini berarti varian yang terjadi pada variabel kesiapan berwira usaha $18 \%$ dipengaruhi oleh implementasi praktik berbasis industri kewirausahaan. dan sisanya $80 \%$ ditentukan faktor lain

Kedua terdapat hubungan positif dan signifikan antara minat belajar dengan kesiapan berwira usaha, dengan perolehan koefisien determinasi sebesar $(0,806) 2=$ 0,649 dan persamaan regresi $Y^{\prime}=15,99+$ $0,86 \mathrm{X}$. Hal ini berarti varian yang terjadi pada variabel kesiapan berwira usaha $65 \%$ dipengaruhi oleh minat dan sisanya 35\% ditentukan faktor lain.

Ketiga terdapat hubungan positif dan signifikan antara kreativitas dengan kesiapan berwira usaha, dengan perolehan koefisien determinasi sebesar $(0,513) 2=0,263$ dan persamaan regresi $Y^{\prime}=50,13+0,44 X$. Hal ini berarti varian yang terjadi pada variabel kesiapan berwira usaha $26,3 \%$ dipengaruhi oleh kreativitas siswa dan sisanya 73,7\% ditentukan faktor lain.

Keempat terdapat hubungan positif dan signifikan antara implementasi praktik berbasis industri kewirausahaan, minat belajar, dan kreativitas dengan kesiapan berwira usaha, dengan perolehan koefisien determinasi sebesar $(0,665) 2=0,442$ dan persamaan regresi $\mathrm{Y}^{\prime}=9,351+0,321 \mathrm{X} 1+$ $0,334 \mathrm{X} 2+0,355 \mathrm{X} 3$. Hal ini berarti varian yang terjadi pada variabel kesiapan berwira usaha 44,2\% dipengaruhi oleh implementasi praktik berbasis industri kewirausahaan, minat belajar, dan kreativitas, sisanya 55,8\% ditentukan faktor lain. 


\section{DAFTAR PUSTAKA}

Djamarah, S. B. (2005). Guru dan Anak Didik Dalam Interaksi Edukatif. Jakarta: Rineka Cipta.

Hamdani. (2011). Strategi Belajar Mengajar. Bandung: Pustaka Setia

Sudaryono. (2012). Dasar-dasar Evaluasi Pembelajaran. Yogyakarta: Graha Ilmu.

Sugiyono. (2010). Metode Penelitian Pendidikan Pendekatan Kuantitatif, Kualitatif, dan R\&D. Bandung: Alfabeta.

Timmons, J. A. (1978). Characteristics and Role Demands of Entrepreneurship. American Journal of Small Business, 3(1), 5-17. https://doi.org/10.1177/104225877800300102

BPS. (2012). Pada Agustus 2012, Tingkat Pengangguran Terbuka (TPT) Sebesar 6,14 Persen. Retrieved from https://www.bps.go.id/pressrelease/2012/11/05/65/pada-agustus-2012--tingkat-pengangguran-terbuka--tpt-sebesar-6-14-

persen.html\#: :text=Tingkat\%20Pengangguran\%20Terbuka\%20(TPT)\%20di,2011\%20sebesar\%206\%2C56 $\% 20$ persen. 